DOI: https://doi.org/10.18371/fp.3(35).2019.190151

УДК 368.03:657.631.6

\title{
ШЛЯХИ ПОДОЛАННЯ АСИМЕТРІЇ ІНФОРМАЦІЇ МІЖ ОСНОВНИМИ КОНТРАГЕНТАМИ СТРАХОВИХ КОМПАНІЙ
}

\author{
БАРАНОВ Андрій Леонідович \\ кандидат економічних наук, доиент \\ в.о. завідувача кафедри страхування \\ ДВНЗ «КНЕУ імені Вадима Гетьмана» \\ ORCID ID: http://orcid.org/0000-0003-0032-3128 \\ e-mail:andriy.baranov@ukr.net
}

Анотація. У статті досліджено існуючі підходи протидї проблемам, пов'язаним із асиметрією інформачії. Для страхових компаній запропоновано розділити шляхи подолання цієї асиметрії на дві групи залежно від специфіки конфлікту інтересів, щуо виникає між ї̈ основними стейкхолдерами. Розкрито иляхи подолання асиметрії інформачії між страховиком та страхувальником, менеджментом страхової компанії, ї̈ власниками та кредиторами.

Ключові слова: асиметрія інформації, страховик, страхувальник, теорія скринінгу, теорія ринкових сигналів, інфраструктура страхового ринку.

Постановка проблеми. Інформація стає вирішальним та спонукальним фактором прийняття управлінських рішень на будь-якому рівні. Від іiі повноти та якості залежать ефективність та результативність цих рішень. Отже, виникає проблема як забезпечити рівний доступ всім учасникам до необхідної їм інформації, як протидіяти асиметрії інформації.

Однією 3 основних причин виникнення суперечностей між сторонами
Аннотация. В cmaтье исследованы существуюшие подходы противодействия проблемам, связанным с асимметрией информачии. Для страховых компаний предложено разделить пути преодоления этой асимметрии на две группы в зависимости от специфики конфликта интересов, возникающего между ее основными стейкхолдерами. Раскрыты пути преодоления асимметрии информации между страховщиком и страхователем, менеджментом страховой компании, ее собственниками и кредиторами.

Ключевые слова: асимметрия информации, страховщик, страхователь, теория скрининга, теория рыночных сигналов, инфраструктура страхового рынка.

страхового процесу $\epsilon$ існування асиметричності інформації. Особливу роль вона відіграє на страховому ринку, де власне реалізуються економічні відносини між страховиком і страхувальником щодо передавання страхового ризику за певну плату з метою отримання в майбутньому страхової виплати в разі настання страхового випадку. Асиметрія інформації породжує проблеми несприятливого вибо- 
ру, морального ризику та інформаційної монополії.

Аналіз останніх досліджень та публікацій. Проблема асиметрії інформації в економіці є предметом дослідження багатьох науковців. Значний внесок у розкриття ії причин і наслідків зробили лауреати Нобелівської премії 2001 р. Дж. Акерлоф, М. Спенс, Дж. Стігліц [1; 2]. Їхні наукові праці дали поштовх дослідженню впливу асиметрії інформації на діяльність різних інституцій, зокрема фінансових.

Серед вітчизняних учених, які досліджували окремі питання асиметрії інформації в економіці, слід відзначити праці К. Ковальської [3], Г.В. Кравчук [4], О.В. Лунякова [5], Н.П. Мацелюх [6], В.І. Огієнка [5], О.Л. Пластуна [4], О.В. Приз [7], В.І. Шевчук [4]. Утім, аналіз публікацій показав, що інформаційна асиметрія на страховому ринку та шляхи боротьби з нею залишаються малодослідженими. Учені, які розглядали детально аспекти існування цієї асиметрії в цілому, не досліджували специфіку іiі існування на страховому ринку, а учені, які займалися дослідженням окремих проблем страхування, не розглядали асиметрію інформації.

Мета статті полягає у теоретикометодологічному обгрунтуванні шляхів подолання асиметрії інформації між основними контрагентами страхових компаній.

Виклад основних результатів. Дж. Акерлоф першим спробував обгрунтувати інституційні механізми протидії проблемам, пов'язаним із асиметрією інформації. До них він відніс гарантії, фірмові знаки та ліцензування [1]. Наявність гарантії на окремий товар, як правило, іiі мають споживчі товари тривалого користування, свідчить про те, що товар відповідає певному нормальному очікуваному рівню. Проте інститут гарантії досить обмежений у використанні. Наприклад, на страхові послуги страховик дати гарантію не може, оскільки сама страхова послуга за своєю суттю є обіцянкою, а обіцяючи дотриматися своєї обіцянки страховик навряд чи підвищить рівень довіри до себе. «Фірмові знаки не тільки свідчать про якість товару, а й дають покупцеві можливість вжити заходів у відповідь, якщо якість покупки не відповідає його очікуванням - він просто не буде більше купувати продукцію цієї фірми» [1]. Страхувальник, який залишився не задоволений діями страховика, може відмовитися від користування його послугами та звернутися до іншої страхової компанії. Заодно він може порадити всім своїм родичам та знайомим теж не користуватися послугами відповідної компанії. «Практика ліцензування також зменшує невизначеність якості» [1]. Наявність ліцензії на здійснення певного виду страхування у страхової компанії свідчить про виконання нею ліцензійних умов щодо провадження страхової діяльності, що підтверджено регулятором. На жаль, в Україні така практика немає реального втілення. Протягом 2015-2016 pр. збільшилась кількість випадків, коли страхові компанії, маючи відповідні ліцензії, переставали виконувати свої зобов'язання перед клієнтами (ПрАТ «СК «ЕККО», СК «НОВА», ПАТ «СК «СКАЙД»).

Основою методів боротьби з інформаційною асиметрією виступила «теорія ринкових сигналів» М. Спенса, 
згідно з якою продавці мають надавати додаткову інформацію про якість своїх товарів. Це забезпечить протидію несприятливому відбору і збереже ефективність ринку. В ролі такої додаткової інформації на рівні компаній можуть виступати фірмові знаки, торгові марки, гарантії, репутація фірми, сертифікати якості, дипломи різних конкурсів та престижні номінації, рекомендації, кваліфікація, а також виплата дивідендів як сигнал благополуччя та добрих перспектив [4].

Концепція або теорія скринінгу, первинні дослідження якої було розпочато Дж. Стігліцом та М. Ротшильдом у своїй спільній праці, «передбачає що менш поінформований клієнт може спонукати контрагента до розкриття більшого, ніж початкового, обсягу інформації, задаючи відповідні питання та уточнюючи умови контракту» [8]. Свої дослідження вони проводили на прикладі страхового ринку, де визначали, що страховики, як погано інформовані особи, через меню альтернативних страхових контрактів (різні поєднання премій i франшиз) здатні визначити ступінь ризику страхувальника, як добре поінформованої особи.

Величина франшизи, яку вибирає індивідуум при купівлі страхового полісу, може передавати інформацію про його точку зору на ймовірність настання страхового випадку та масштаб втрат, які він у зв'язку із цим очікує [2]. Таким чином Дж. Стігліц приходить до висновку про можливість впровадження механізмів самовідбору: «люди, які знають, що вони менш вразливі до нещасних випадків, проявляють більшу готовність до придбання полісів $з$ великою франшизою, i, таким чином, страхова компанія, пропонуючи два види полісів, один - 3 високою премією та без франшизи, а інший - 3 низькою премією та великою франшизою, може виокремити високоризикових клієнтів від низько ризикових [2].

Ми повністю погоджуємося 3 методами боротьби 3 інформаційною асиметрією, які запропонували вітчизняні вчені Г.В. Кравчук, В.І. Шевчук, О.Л. Пластун [4], проте вони носять загальний характер, тобто не враховують специфіку окремих видів діяльності та учасників ринку, і сформульовані 3 метою забезпечення фінансової безпеки загалом. Нас, звичайно, цікавлять саме страхові компанії та інструменти, які вони можуть використовувати для боротьби з асиметрією інформації.

Так, Г.В. Кравчук, В.І. Шевчук, О.Л. Пластун пропонують 4 групи методів, що сприяють зниженню інформаційної асиметрії в економіці: генерація сигналів, внутрішньо фірмові важелі, державне регулювання та наявність баз даних [4]. Оскільки страхова компанія має цілий ряд різних суперечностей, що виникають між різними зацікавленими особами, то сформувати єдиний підхід або єдиний набір засобів протидії асиметрії інформації неможливо. Розділимо всі суперечності, пов'язані 3 функціонуванням страхової корпорації як суб'єкта підприємницької діяльності на дві групи:

1. суперечності, пов'язані 3 особливостями страхових відносин, які виникають між страховиком та страхувальником (конфлікт інтересів між страховиком та страхувальником 3 приводу оцінки величини ризику, супроводу договору страхування, 
здійснення страхової виплати тощо; конфлікт інтересів, що виникає між страхувальниками та менеджментом страхових компаній щодо участі в розподілі прибутку);

2. суперечності, пов'язані 3 особливостями функціонування страховика у формі страхової компанії (конфлікт між менеджерами та акціонерами страхової компанії, конфлікт між акціонерами та кредиторами страхової компанії, конфлікт між менеджерами страхової компанії та менеджерами інших компаній, які виступають об'єктом інвестування коштів у їхні корпоративні права, конфлікт інтересів між менеджерами страхової компанії та менеджерами інший компаній, які намагаються придбати або поглинути іiі).

Для першої групи суперечностей для уникнення асиметрії інформації для страховика можна виділити такі інструменти, які базуються на теорії скринінгу Дж. Стігліца:

заповнення страхувальником заяви, а в разі необхідності й анкети, про страхування, де потрібно розкрити всю інформацію про об'єкт страхування, яка йому відома, та яка необхідна страховику для здійснення оцінки ризику. Зокрема, інформацію про технічний стан об'єкта страхування, його дійсну вартість, можливі фактори підвищеного ризику, негативний стан здоров'я (у разі страхування життя чи здоров'я), негативне фінансове становище (у разі страхування відповідальності), інформацію про страхові випадки в минулому та фактичні розміри збитків за результатами таких випадків тощо. Обсяг та повнота інформації може варіювати залежно від виду страхування, складності об’єкту тощо. Для того щоб убезпечити себе від подання свідомо неправдивої інформації наприкінці заяви страховиком наводиться пункт про те, що страхувальник підтверджує правдивість та повноту наведеної інформації та попереджений, що в разі виявлення недостовірних відомостей про обставини, які мали істотне значення для визначення ймовірності настання страхового випадку і розміру можливої шкоди у разі його настання, страховик має право відмовити у здійсненні страхової виплати. Цю інформацію та факт ознайомлення 3 останнім пунктом страхувальник підтверджує своїм підписом;

- визначення в умовах договору страхування відповідальності страхувальника та санкцій за подання свідомо неправдивої інформації про об’єкт страхування, а також інформації, яка стала йому відома під час дії договору та може вплинути на величину ризику за ним; обмежень та винятків зі страхування; переліку страхових випадків; процедури та строків здійснення страхової виплати; відповідальності страхувальника за неналежне поводження $з$ об'єктом страхування та невжиття заходів по його рятуванню в разі настання страхового випадку; застереження щодо поводження 3 об'єктом страхування, так ніби він і не був застрахованим, тощо;

- визначення договором страхування розміру страхового покриття, виду та величини франшизи, страхової суми, лімітів відповідальності загалом та за одним випадком, системи страхового забезпечення та ін.;

- здійснення огляду об'єкта страхування представниками страхо- 
вика (при страхуванні майна), проведення медичного огляду в лікарнях, визначених страховиком (при страхування життя або здоров'я), фізичний контроль за виконанням програми рекомендацій для зменшення величини ризику, виїзд на місце настання страхового випадку та огляд пошкодженого об'єкта, з'ясування причин та обставин настання страхового випадку власними силами чи силами сюрвеєрів або аджастерів тощо.

Крім формальних процедур, страховик може застосовувати і неформальні процедури, які зводяться до відмови у прийнятті ризику на страхування; пропозиції страхувальнику завідомо невигідних умов страхування; розроблення нездійсненної програми рекомендацій та зауважень, які страхувальник повинен виконати для прийняття ризику на страхування або яким повинен слідувати протягом дії договору страхування; залучення сюрвеєрських компаній, що спеціалізуються на оцінці об'єктів за певними видами страхування, для визначення якомога точнішої величини ризику або відмови у здійсненні страхової виплати через порушення умов договору.

Як висновок, можна відзначити, що у страховика більше, ніж достатньо, інструментів для протидії проблемам, пов'язаним із асиметрією інформації. Проте, застосування цих інструментів породжує значні витрати (так звані трансакційні витрати, пов'язані з пошуком інформаціі). Тому основною проблемою страховика залишається визначення того мінімального обсягу інформації, який йому потрібен для прийняття рішення про страхування ризику та на яких умовах, а також який він буде згоден оплатити. На практиці це питання може вирішуватися за допомогою розроблення стандартних договорів страхування зі стандартними умовами зі стандартною процедурою проведення андерайтингу силами страхових агентів для більшості страхувальників-фізичних осіб. А для складних ризиків, 3 великими страховими сумами та ризиків переважно юридичних осіб здійснювати процедуру індивідуального андерайтингу, при необхідності залучати сюрвеєрів тощо.

Для уникнення асиметрії інформації для страхувальника можна виділити такі шляхи:

- детальне ознайомлення страхувальника 3 умовами та правилами страхування, що відповідають чинному законодавству;

- наявність у страховика свідоцтва про внесення до державного реєстру фінансових установ України, ліцензії на здійснення страхової діяльності за тим видом щодо якого укладається договір страхування, відповідних правил страхування, затверджених в Уповноваженому органі;

- наявність власного вебсайту, на якому можна ознайомитися 3 інформацією про бенефіціарів страховика, звітами про фінансовий стан, інформацією про виконання страховиком страхових зобов'язань (дані про виплати, про їх розміри тощо);

- фірмовий знак або бренд страхової компанії. Якщо компанія заслужила свій бренд успішною та тривалою роботою на страховому ринку, то це має гарантувати потенційним страхувальникам дотримання таких стандартів у роботі компанії й на- 
далі. Особливо, коли компанія має іноземний капітал, іноземних власників або взагалі цілу потужну материнську страхову корпорацію, відому у всьому світі, то вона повинна дотримуватися відповідних стандартів ведення бізнесу. Адже проблеми однієї 3 компаній, що входить до міжнародної страхової групи, можуть відобразитися на всій групі, iї реноме у світі;

ділова репутація компанії, яка склалася на ринку. Як відносяться до компанії інші страховики-партнери, перестраховики, як відзиваються про компанію іiі чинні та колишні клієнти;

\section{- отримання у представника} роз'яснення умов страхування, особливо щодо таких складних опцій, як вид та величина франшизи, перелік ризиків, які покриваються договором, а які ні, процедура визначення розміру страхової виплати, строки виплати в разі настання страхового випадку;

- виплата компанією дивідендів своїм акціонерам. На думку, М. Спенса це потужний сигнал для ринку про те, що в компанії все в порядку, вона успішно працює, отримує позитивний фінансовий результат.

Реалізувати ці шляхи страхувальник може за допомогою пошуку інформації самостійно або за допомогою страхового брокера, який за комісійну винагороду зможе вирішити всі питання щодо пошуку інформації про кращого страховика та оптимальні умови страхування, а також зможе допомогти при настанні страхового випадку.

Як бачимо, у страхувальника перелік можливих інструментів для отримання повної та правдивої інформації про страховика, його фінансовий стан та умови страхування не так багато.
Тому в цьому випадку обов'язково має втручатися держава у вигляді регулятора, який повинен забезпечити прозоре інформаційне поле для потенційних страхувальників та встати на їхній захист в разі порушення їх прав. Регулятор забезпечує можливість використання таких заходів:

- здійснення ліцензування страхової діяльності;

- $\quad$ проведення сертифікації вищого менеджменту страхової компанії (в Україні на сьогодні це сертифікація керівника та головного бухгалтера);

- реєстрація правил страхування;

- $\quad$ здійснення фінансового моніторингу;

- $\quad$ ведення державного реєстру фінансових установ;

- $\quad$ оприлюднення інформації про зупинення та обмеження діяльності страхових компаній, про введення до них тимчасових адміністрацій, про застосування заходів впливу та стан їх виконання;

- оприлюднення переліку страхових компаній, щодо яких регулятором зафіксовано найбільше скарг.

На сучасному етапі розвитку страхового ринку України дієвим механізмом могло би стати створення Фонду гарантування виплат за договорами страхування життя. Це був би потужний сигнал для всього ринку та суспільства про надійність ринку страхування життя, який би знизив рівень інформаційної асиметрії між населенням та компаніями, що здійснюють страхування життя.

Окрім держави, на нашу думку, забезпечувати інформацією основних 
учасників страхового ринку мають інститути його інфраструктури:

створення саморегулівної організації (СРО), яка могла би на себе перейняти частину функцій держави щодо атестації та сертифікації кадрів страхових компаній, розроблення «кодексу етики страховика», відслідковувати інформацію про страховиківчленів цієї СРО та оприлюднювати іiі;

- біржова інформація, тобто інформація про фінансову діяльність страховиків (хто які ресурси залучає, хто випускає боргові, а хто пайові цінні папери), яка б свідчила про реальний стан речей в компанії, про наявність власних коштів для розвитку власного бізнесу, про потребу у кредитних коштах тощо;

рейтинги від рейтингових агентств. Це дуже перспективний напрямок для полегшення та зменшення витрат на пошук інформації страхувальниками. Страхувальник ознайомившись 3 рейтингом страхової компанії, 3 його динамікою за останній період може прийняти рішення про те, чи слід звертатися до такої компанії, чи ні. Проте, вітчизняні та окремі міжнародні рейтингові агентства дещо підірвали рівень довіри до рейтингів, що ними встановлюються. Наприклад, банк «Хрещатик» отримав рейтинг за національною шкалою, а через незначний час був визнаний неплатоспроможним та до нього було введено тимчасову адміністрацію. Тому діяльність рейтингових агентств повинна бути взята під державний нагляд.

Наступним $є$ конфлікт інтересів, що виникає між страхувальниками та менеджментом страхових компаній щодо участі в розподілі прибутку. У цьому питанні ми повністю підтримуємо позицію К.Г. Воблого [9] про можливість створення спеціального комітету для постійного контролю над ходом справ у компанії. Але, також слід розуміти, що страхові компанії навряд чи підуть на такий крок. Для них це може обернутися, по-перше, створенням додаткового контролера в пару до контрольних органів акціонерів, а, подруге, утримання такого комітету може призвести до значних витрат. Для вирішення цієї суперечності необхідне втручання держави. Або держава законодавчо закріпить необхідність формування такого органу контролю 3 боку страхувальників та уповноважить регулятора страхового ринку здійснювати нагляд за дотриманням прав страхувальників, або визначити на законодавчому рівні підходи до визначення розміру частини прибутку, що може розподілятися між страхувальниками, та процедури здійснення такого розподілу. В цьому разі страховики змушені будуть дотримуватися норм законодавства, а в разі їх порушення страхувальники будуть мати підстави для апелювання до страховика або інших органів. На нашу думку, цей варіант $є$ більш реальним щодо його впровадження.

Вищезазначені шляхи подолання асиметрії інформації між основними контрагентами систематизовано у табл. 1. 
Таблиця 1

Шляхи подолання асиметрії інформації між основними контрагентами страхових компаній

\begin{tabular}{|c|c|c|}
\hline $\begin{array}{c}\text { Асиметрія інфор- } \\
\text { мацї̈ }\end{array}$ & $\begin{array}{c}\text { Основні контра- } \\
\text { генти }\end{array}$ & Шляхи подолання асиметрії інформації \\
\hline \multirow{4}{*}{$\begin{array}{l}\text { Несприятливий } \\
\text { вибір. } \\
\text { Моральний ризик. } \\
\text { Інформаційна моно- } \\
\text { полія. } \\
\text { Проблема «принци- } \\
\text { пал-агент». }\end{array}$} & Держава & $\begin{array}{l}\text { - Інформування про введення тимчасових адміні- } \\
\text { страцій до страхових компаній. } \\
\text {-Інформування про зупинення та/або обмеження } \\
\text { діяльності страхової компанії. } \\
\text {-Інформування про застосування заходів впливу } \\
\text { та стан їх виконання. } \\
\text {-Перелік страхових компаній щодо яких регуля- } \\
\text { тором зафіксовано найбільше скарг. } \\
\text { - Закріплення на законодавчому та нормативному } \\
\text { рівнях вимог щодо процедури та розмірів участі } \\
\text { страхувальників у прибутку страховика. } \\
\text { Фінансовий моніторинг. } \\
\text { - Ведення ДРФУ. } \\
\text {-Реєстрація правил страхування. } \\
\text {-ертифікація. } \\
\text { - Ліцензування. }\end{array}$ \\
\hline & $\begin{array}{l}\text { Інфраструктура } \\
\text { страхового ринку }\end{array}$ & $\begin{array}{l}\text {-Наявність СРО. } \\
\text {-Біржова. Інформація. } \\
\text { Рейтинги від рейтингових агентств. }\end{array}$ \\
\hline & Страхувальник & $\begin{array}{l}\text { - Використання послуг страхового брокера. } \\
\text {-Наявність веб-сайту страхової компанії з інфо- } \\
\text { рмацією про умови страхування, фінансовй } \\
\text { стан страховика, про бенефіціарів страхової } \\
\text { компанії. } \\
\text {-Правила страхування. } \\
\text { - Наявність саll-центру. } \\
\end{array}$ \\
\hline & Страховик & $\begin{array}{l}\text { Формальні процедури } \\
\text {-Заява та анкета про страхування. } \\
\text { - Договір страхування. } \\
\text {-Огляд майна (передстрахова експертиза). } \\
\text {-Медичний огляд застрахованих осіб. } \\
\text {-Огляд пошкодженого майна. } \\
\quad \underline{\text { Неформальні процедури }} \\
\text {-Відмова у страхвванні. } \\
\text {-Пропозиція невигідних умов страхування. } \\
\text { - Розробка нездійсненної програми рекомендацій } \\
\text { та зауважень. } \\
\text { - Залучення експертів при врегулюванні збитків } \\
\text { (сюрвеєрів, аджастерів). } \\
\text {-Відмова у страховій виплаті }\end{array}$ \\
\hline
\end{tabular}


Для другої групи суперечностей для уникнення асиметрії інформації можна виділити такі інструменти:

винагорода менеджерів. Така винагорода повинна забезпечувати виконання двох цілей: залучати та утримувати в компанії компетентних менеджерів і максимально наближати їх дії до забезпечення інтересів акціонерів. На думку Ю. Брігхема та М. Ерхардта [10, с. 49-50], компенсаційний пакет вищого менеджменту корпорації складається з трьох компонентів: 1) фіксованої щорічної платні; 2) грошових премій або преміальних акцій за результатами року і 3) фондових опціонів на придбання акцій фірми за довгострокову ефективну працю на благо компанії;

- з загроза звільнення менеджменту страхової корпорації. Якщо дії менеджменту компанії не відповідають інтересам акціонерів, то вони можуть на чергових або позачергових зборах акціонерів звільнити такий менеджмент. У США це досить проблематично, оскільки акції окремих корпорацій можуть бути розпорошені серед дуже великої кількості акціонерів, а контроль менеджерів за механізмом голосування є великим. В Україні, це зробити простіше, оскільки серед вітчизняних страхових корпорацій немає такої розпорошеності акцій, контрольний пакет завжди зосереджений в руках невеликої кількості акціонерів;

- загроза поглинання. Суть цього інструменту детально розкрита в межах теорії корпоративного контролю;

безпосереднє втручання акціонерів в оперативне управління компанією. Менеджмент страхової корпорації може втручатися в управління компанії, акціонером якої $\epsilon$ страховик: по-перше, вони можуть спілкуватися 3 менеджерами фірми i вносити різноманітні пропозиції, що стосуються методів ведення бізнесу, по-друге, висувати офіційні пропозиції, які відповідно до законодавства повинні голосуватися на щорічних зборах акціонерів, навіть якщо ці пропозиції не влаштовують менеджерів $[10$, c. 52];

- використання боргових контрактів. «Боргові контракти - це зобов'язання 3 боку фірми виплачувати певну фіксовану суму інвестору в ролі доходу на його інвестиції. Такий підхід, на відміну від участі інвестора у прибутках і отриманні певної їх частки за результатами роботи за період, знижує ймовірність виникнення морального ризику та опортуністичної поведінки 3 боку керівників компанії» [4]. Менеджменту страховика не потрібно нести значні витрати по контролю за менеджментом компанії, інституційним інвестором якої вони $\epsilon$, оскільки в цьому випадку менеджмент зацікавлений в успішній роботі компанії та отриманні якомога більших прибутків, щоб можна було розрахуватися 3 інвестором та суму перевищення залишити собі, частина з якої може піти на бонуси менеджменту;

застосування так званих обмежувальних заходів (restrictive covenants) - чітко прописаних в контракті меж допустимих дій з боку менеджменту компанії та їх повноважень [4]. Цей інструмент може бути ефективним як при вирішенні конфлікту між менеджерами та акціонерами, так i між акціонерами та кредиторами. В 
першому випадку в контракті між менеджментом та акціонерами, а в другому - між менеджментом та кредиторами прописуються обмеження щодо дій менеджменту в певних ситуаціях, участі в ризикових проектах, можливості збільшення кредиторської заборгованості, розголошення інформації тощо;

проведення аудиторських висновків фінансової звітності компаній дає певні позитивні сигнали ринку та формує довіру до компанії з боку страхової корпорації як інституційного інвестора, вливаючи на прийняття нею інвестиційного рішення. Звичайно, що аудиторський висновок не продукує нову інформацію для ринку, він просто підтверджує існуючу інформацію про фінансовий стан компанії. Крім цього, репутація аудиторської компанії може бути додатковим сигналом зниження інформаційної асиметрії. Показовим прикладом у цьому ракурсі $\epsilon$ доля аудиторської фірми «Артур енд Андерсен» (входила в п’ятірку найбільших аудиторських компаній світу), яка після скандалу 3 «Енрон» змушена була припинити своє більш ніж сторічне існування, оскільки втратила репутацію [4];

$$
\text { - оприлюднення результатів }
$$

аналізу поточного стану компанії та прогнозів щодо іiі майбутніх перспектив фінансовими аналітиками, які виконують інформаційну функцію на фінансових ринках. Г.В. Кравчук, В.I. Шевчук, О.Л. Пластун стверджують, що «результати наукових досліджень діяльності фінансових аналітиків на ринках капіталів свідчать, що фінансові аналітики здійснюють вплив на вартість активів компанії на ринку.
При чому прогнози аналітиків, як правило, більш якісні, ніж звичайний аналіз компанії чи цін на їі акції, оскільки враховують не лише суто внутрішньофірмову інформацію, але й інформацію 3 зовнішнього середовища економічні новини, політичні події тощо» [4].

Висновки. Однією з основних причин виникнення суперечностей між сторонами страхового процесу $є$ існування асиметрії інформації. Шляхи іiі подолання між основними контрагентами страхової компанії систематизовано в розрізі двох груп суперечностей: пов'язаних 3 особливостями страхових відносин, які виникають між страховиком та страхувальником (конфлікт інтересів між страховиком та страхувальником 3 приводу оцінки величини ризику, супроводу договору страхування, здійснення страхової виплати тощо; конфлікт інтересів, що виникає між страхувальниками та менеджментом страхових компаній щодо участі в розподілі прибутку) та пов'язаних 3 особливостями функціонування страховика у формі страхової корпорації (конфлікт між менеджерами та акціонерами страхової компанії, конфлікт між акціонерами та кредиторами страхової компанії, конфлікт між менеджерами страхової компанї та менеджерами інший компаній, які виступають об'єктом інвестування коштів у їхні корпоративні права, конфлікт інтересів між менеджерами страхової компанії та менеджерами інший компаній, які намагаються придбати або поглинути іiі). 
Список використаної літератури

1. Akerlof George A. The Market for «Lemons»: Quality Uncertainty and the Market Mechanism. The Quarterly Journal of Economics. August 1970. V. 84. P. 488-500.

2. Матеріали виступу Дж. Стігліца при одержанні Нобелівської премії 3 економіки 8 грудня 2001 року у скороченому вигляді. URL: http://www.ufin.com.ua/analit_mat/poradnyk/154.htm (дата звернення: 13.06.2018). 3. Ковальська К. Сутність і особливості управління конфліктами інтересів у корпорації. Вісник Київського національного університету імені Тараса Шевченка «Економіка». 2011. № 121-122. С. 86-89.

4. Кравчук Г.В., Шевчук В.І., Пластун О.Л. Боротьба з інформаційною асиметрією як важлива складова забезпечення фінансової безпеки. Вісник Чернігівського державного технологічного університету. 2013. № 1 (64). С. 213-220.

5. Огієнко В.І., Луняков О.В. Асиметрія інформації в інвестиційних процесах. Актуальні проблеми економіки. 2012. № 1 (127). С. 320-334.

6. Мацелюх Н.П. Асиметрія інформації, як фактор дисбалансів ціноутворення на фінансовому ринку: теоретичний аспект. Збірник наукових праць Національного університету державної податкової служби України. 2013. № 2. С. 88-95.

7. Приз О.В. Асиметричність інформації в глобальній економіці. Вісник Дніпропетровського університету. Серія «Менеджмент інновацій». 2014. Випуск 3. С. 69-73.

8. Юркевич О.М., Власова І.В. Асиметрія інформації в дослідженні інформаційної прозорості фінансових установ. Інновачійні напрямки розвитку страхового ринку Украӥни: збірник матеріалів III Міжнар. наук.-практ. конф., 19-20 квітня 2016 р. Київ: КТ «Забєліна-Фільковська Т.С. і компанія Київська нотна фабрика», 2016. С. 398-401.

9. Воблый К.Г. Основы экономии страхования. Москва: Изд. центр «Анкил», 1993. 228 с. Перераб. версия труда акад. К.Г. Воблого, изд. в 1925 г.

10. Бригхэм Ю., Эрхардт М. Финансовый менеджмент. 10-е изд. / пер. с англ. под. ред. к.э.н. Е.А. Дорофеева. Санкт-Петербург: Питер, 2009. 960 с. 